\author{
Lesya ZABURANNA ${ }^{1}$ \\ Nataliia GERASYMCHUK ${ }^{2}$
}

\title{
OPTIMIZATION OF AGRICULTURE PRODUCTION ON THE BASIS OF RESOURCE SAVING STRATEGY
}

\begin{abstract}
The author in the article discusses the need and possibility of developing resource saving strategy using instruments of cooperation and specialization, providing clear results of implementing of developed optimal structure of agricultural production. Resource saving as an activity represents actions of the various economic agents with continuous improvement of exploitation of productive resources and steps to establish the economic mechanism of saving of production resources, consisting of a resources, management , financing, incentives and more. Developing and improving resource saving strategy require evaluation of large, medium, small and specialized farms, based on their close cooperation and interaction that involves specialization. Usage of the concentration and specialization theory gives the resource saving strategy solid ground and advantages of adequate planning, high accuracy levels for the foreseeable future, understanding of key performance indicators, selection of the most efficient (optimal) decisions on the allocation and use of resources, to ensure the greatest volume of production or the least cost pricing. At the same time, we believe that the process of resource saving reflects the most important resource and sustainable relationships and interdependencies that directly cover the main aspects of the economic activities at all levels of the economy. The process of implementing of resource saving strategy is solving conflicts between resource-saving effect of new technology and adaptive capabilities of the existing economic mechanism, increasing of the productive forces of enterprise in future.
\end{abstract}

Keywords: resource saving, concentration, specialization, optimal size, agricultural production.

\section{INTRODUCTION}

Resource saving as an activity represents actions of the various economic agents with continuous improvement of exploitation of productive resources and steps to establish the economic mechanism of saving of production resources, consisting of a resources, management, financing, incentives and more. Resource saving strategy is always personalized, it may be a single person, company, industry, region, state. Therefore, the resource saving strategy is realized through the activities of businesses.

\footnotetext{
${ }^{1}$ Prof. Lesya Zaburanna, professor of management department of National University of Life and Environmental Sciences of Ukraine.

${ }^{2} \mathrm{PhD}$ Nataliia Gerasymchuk, Associate Professor of Department of Economics of Enterprises, National University of Life and Environmental Sciences of Ukraine, Heroyiv Oborony st., 15, Kyiv - 03041, Ukraine, corresponding author: e-mail: 90999nag@ mail.ru
} 
Developing and improving resource saving strategy require evaluation of large, medium, small and specialized farms, based on their close cooperation and interaction that involves specialization.

The problems of resource provision of economic subjects in agriculture had been analyzed in the works of many well-known Ukrainian scientists such as Andriichuk V.G., Geets V.M., Gorovyi V.P., Zinovchuk V.V., Il'chuk M.M., Malik M.I., Tereshchenko V.K., Tkachuk V.A., Yurchishin V.V. and many others. Despite the rather detailed analysis of the problem, the current state of agricultural sector in the context of sustainable development throws new challenges to be addressed, one of the most pressing is the issue of resource saving. But before finding the solution to any problem, the first step is to analyze and collect data on the situation, the action this article is dedicated to.

\section{MECHANISM OF RESOURCE SAVING ACTIVITY IN AGRICULTURE PRODUCTION}

Within the different economic categories resource saving can be distinguished as set of regular connections between elements that reflect each of the subsystems of integrated economic system, as shown on Figure 1. In addition to these components and structural elements of the category, some elements of economic mechanism could be added, for example the impact on the relevant market and economic relations regulation.

Fig. 1. Structure of resource saving activity mechanism.

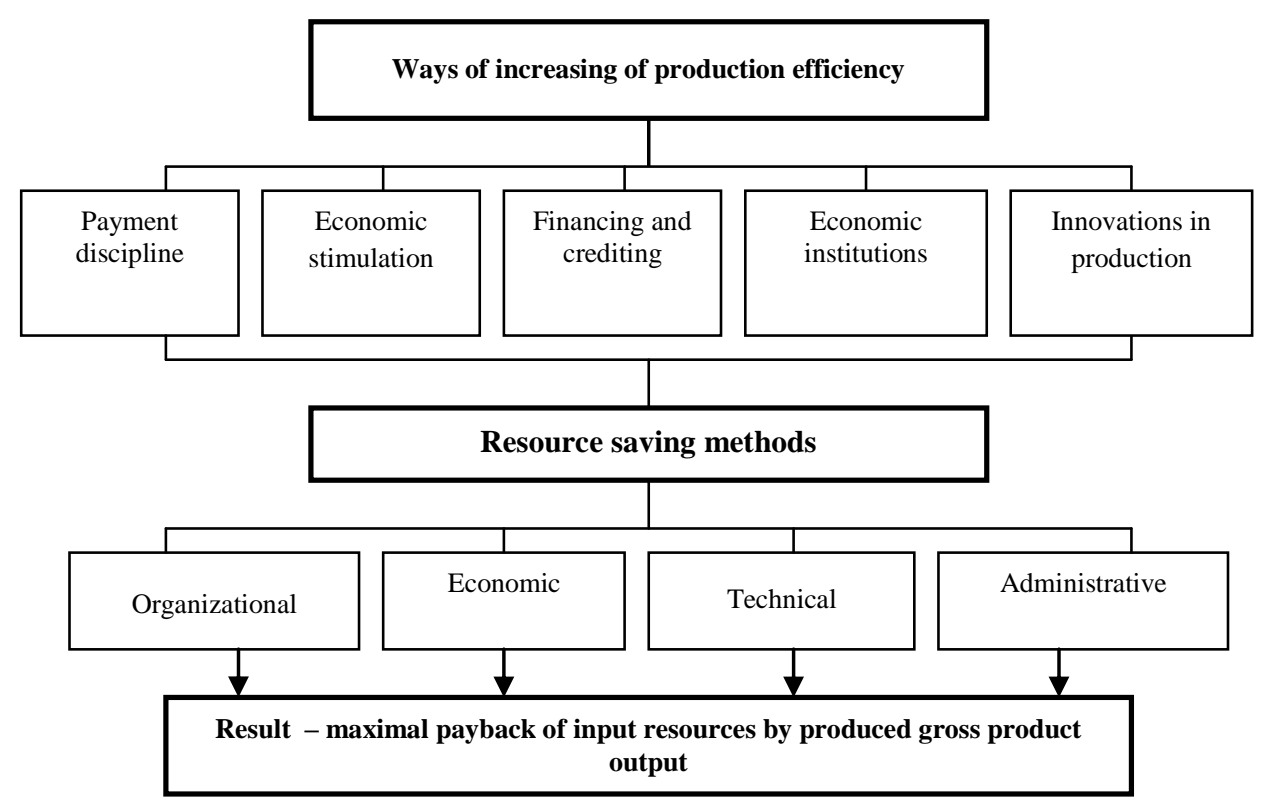

In our opinion, in the narrow sense the resource saving activity is the process of specific economic activities, aimed at achieving specific goals.

Specific objectives, as the results of resource saving strategy, may be briefly described as increase of economic efficiency by reducing its resource usage . 
At the same time, we believe that the process of resource saving reflects the most important resource and sustainable relationships and interdependencies that directly cover the main aspects of the economic activities at all levels of the economy. The process of implementing of resource saving strategy is solving conflicts between resource-saving effect of new technology and adaptive capabilities of the existing economic mechanism, increasing of the productive forces of enterprise in future.

One of the important directions of resource saving in agriculture is to optimize the size of farms and agriculture enterprises. The theory and practice of agricultural production confirms feasibility of consolidation of small farm units to optimal size by developing concentration and intensification of production. Of course, small farms are flexible, efficient functioning, they are easier to reconstruct their production structure than large farms. However, as last decades of agriculture development is showing, dominance of only small farms could not be an effective form of resource saving in rural areas.

The most stable appeared to be large-scale structures based on collective forms of management and private ownership of land and property of its members. Based on joint efforts the combined property effectively used that contributes to enlargement of own agricultural capital at the expense of profits and stimulation of industrial and social development dividends. Large-scale agricultural enterprises have more options for comprehensive mechanization of production, big buyer preferences, which increases the productivity of labor and reduces the risks of overhead charges as the result.

The resource saving strategy development on agricultural enterprise should be done through development of technical and agronomic production base and its structural specialization, creating agriculture production complex, which allows to produce the final products and avoid losses during its storage, transportation and sales, the use of more effective system of labor motivation and more.

To increase the resource saving effect on the enterprise it is necessary to concentrate and specialize the agricultural production using advanced technologies. The best is then the agricultural enterprise focuses on the 2-4 most important directions of agricultural production and focuses resources on its development ${ }^{3}$.

In agricultural production concentration made in two forms: general and branch. While the total concentration increases the total volume of agricultural production , the branch is increasing production capacity in one sector. Specialization is most closely associated with concentration of production in industry. In agriculture, the concentration is carried out in various ways. First way of concentration is the union of capital of formerly independent agricultural enterprises, or so-called centralization of production - the consolidation of entire enterprises or part of production through cooperatives. Second way - the concentration of production achieved during its intensification, which is now the main form. On this form of concentration due to increase in yield at the expense of additional investment of material resources and labor, additional capital is forming, which opens possibilities for further expansion. Third way to concentrate agricultural production is carried out by general and production specialization on enterprises. As a result of total concentration, large-scale production is organized of a particular type of product with usage of all of its advantages ${ }^{4}$.

\footnotetext{
${ }^{3}$ Malik Mykola Io, Zinovchuk Vitalii V., Sabluk Petro T., Basics of Agricultural Entrepreneurship, Editor Malik M.Io. - Kyiv, 2001., 582 p. (in Ukrainian).

${ }^{4}$ Pogrebniuak P.L, Intensive beef cattle production in Ukraine, Mocsow, 1979, 239 p.
} 
The benefits of large-scale production over small are shown on merely all conditions with corresponding limits and those benefits are not the same for different sectors of agriculture and various natural and economic conditions. Given this, we studied the dependence of the efficiency of economic activity and the size of land by group analysis (Table 1 ) and the correlation method, which allows us to provide a more complete analysis .

Table 1. Dependence of Indexes of resource saving on the size of the enterprises of Zhytomir region in 2012

\begin{tabular}{|c|c|c|c|c|c|c|}
\hline \multirow{2}{*}{$\begin{array}{c}\text { Groups of enterprises by } \\
\text { the area of agricultural } \\
\text { land, hectares }\end{array}$} & \multicolumn{2}{|c|}{$\begin{array}{c}\text { Number of } \\
\text { enterprises }\end{array}$} & \multicolumn{2}{c|}{ Area of land } & \multicolumn{2}{c|}{$\begin{array}{c}\text { Output of gross } \\
\text { production, UAH }\end{array}$} \\
\cline { 2 - 7 } & $\begin{array}{c}\text { In a } \\
\text { group }\end{array}$ & $\begin{array}{c}\text { percent, } \\
\%\end{array}$ & $\begin{array}{c}\text { ha, } \\
\text { average }\end{array}$ & $\begin{array}{c}\text { share, } \\
\%\end{array}$ & $\begin{array}{c}\text { On 1 } \\
\text { ha of } \\
\text { land }\end{array}$ & $\begin{array}{c}\text { On 100 } \\
\text { UAH of } \\
\text { expenses }\end{array}$ \\
\hline Below 5 ha & 126 & 19,2 & 3,9 & 1,4 & 906 & 99 \\
$6-10$ & 164 & 25,1 & 8,5 & 3,9 & 939 & 103 \\
$11-20$ & 136 & 20,8 & 15,6 & 5,9 & 983 & 108 \\
$21-50$ & 135 & 20,6 & 34,5 & 13,1 & 1014 & 111 \\
$51-100$ & 39 & 6,0 & 69,6 & 7,6 & 1168 & 128 \\
$101-500$ & 39 & 6,0 & 216,7 & 23,8 & 1301 & 142 \\
More than 500 ha & 15 & 2,3 & 1050,3 & 44,3 & 1428 & 156 \\
Total & 654 & 100 & 54,4 & 100 & 1271 & 139 \\
\hline
\end{tabular}

* Source: authors calculations based on data of Agricultural Census of Zhytomir

\section{Oblast 2012}

As can be seen from Table 1, there is a direct correlation between the size of the enterprise and efficiency of its activity.

To determine the correlation between the area of agricultural land (factor rate) and income (loss) per 1 ha of agricultural land by the selection of a mathematical equation that most fully reveals the nature of the interaction between the dependent variable and the factor.

Correlation equation is as follows:

$$
y=19,3+0,076 x
$$

The economic meaning of this regression coefficient is that agriculture enterprises in the study together with an increase in land area also increased their income per 1 ha of agricultural land on average of $76 \mathrm{UAH}$.

The concentration of production could be observed as the size of enterprises and their divisions - working places, farms, shops, stations and so on. Concentration cannot be endless, it could be done to a certain level, after which it loses its effectiveness, which is perfectly described by marginal microeconomic theory.

The best sized enterprises are those which in certain natural economic environment provides the greatest yield and profit at the lowest cost of labor and capital. Excess in size 
over optimum can reduce the efficiency because it increases transportation costs, compounded by the deterioration of labor use and management efficiency .

Agricultural enterprises size in different categories by ownership in Ukraine is shown in Table 2. From the data in table 2 we could make assumption that the largest size of land has state-owned farms - 3.6 thsd hectares, followed by joint-stock companies - 2.2 thsd hectares. Co-operatives and limited liability companies about the same size have 1.8 thsd hectares and is the least private- rental companies - 1.5 thsd hectares.

Table 2.Agricultural enterprises size in Ukraine in $\mathbf{2 0 1 2} *$

\begin{tabular}{|l|c|c|c|c|c|}
\hline \multicolumn{1}{|c|}{ Agricultural enterprises } & \multicolumn{5}{|c|}{ On 1 enterprise } \\
\cline { 2 - 7 } & $\begin{array}{c}\text { Total land } \\
\text { area, ha }\end{array}$ & $\begin{array}{c}\text { Including } \\
\text { agricultural } \\
\text { land }\end{array}$ & $\begin{array}{c}\text { Cattle, } \\
\text { heads }\end{array}$ & $\begin{array}{c}\text { Including } \\
\text { cows }\end{array}$ & $\begin{array}{c}\text { Pigs, } \\
\text { heads }\end{array}$ \\
\hline State enterprises & 3275 & 3209 & 965 & 474 & 742 \\
Business partnerships & 4085 & 3946 & 725 & 342 & 643 \\
Producer's co-operatives & 1800 & 1780 & 680 & 325 & 581 \\
Private enterprises & 1507 & 1450 & 517 & 247 & 611 \\
Private farms & 55 & 55 & 0,66 & 0,31 & 0,90 \\
\hline
\end{tabular}

* Source: authors calculations based on data of Agricultural Census of Ukraine 2012

The biggest farm size groups of all forms of ownership and management is fixed in the Steppe climatic zone - up to 5.6 thsd ha , and the lowest in the Polessye climatic zone 700-900 ha. In the forest-steppe zone the largest farms were under 5 thsd hectares , and the least to 1.5 thsd hectares of agricultural land.

A similar pattern is observed in the zones with cattle breeding. Its greatest number concentrated in state-owned enterprises - about 1000 animals , including about 500 cows , and the lowest - in the private enterprises - respectively 517 and 247 heads. As for the number of pigs , there is no such diversity observed in different organizational and economic structures, as well as the zone differentiation. Needed to be told that big business partnerships rarely keep cattle, since $67.6 \%$ of cattle is on private households, of which 77,6 \% cows. Pigs are more evenly kept - households take $53 \%$ share in total production, which could be explained by recent interest in pig breeding by agro holdings. The farms which are located in different natural and economic zones or have unequal specialization of production subsequently will always have different optimal sizes, which form the requirement for adapted approach to evaluation of optimal size.

The optimal size should have not only enterprise as a whole, but also its structural parts - divisions, brigades, cooperatives working areas to ensure the rational organization 
of land area, livestock keeping with full and effective usage of modern sophisticated technology, employing qualified management and resource saving oriented strategy ${ }^{5}$.

In the process of determining the optimal size of the enterprise first step is to determine the optimal size of the main branches of production. This is best done in the most intense work periods which shows top of their performance, means of production and workers sufficiency and fulfillment of norms of output. Branches of production size should be such that the staff assigned to them promptly and efficiently perform all the work. Excess tension will cause its timing operations, reducing their quality and, consequently, the deterioration of industrial and economic performance in these sectors and the enterprise as a whole.

In the process of optimization such tasks of analysis of organizational and production structure of the enterprise are put: evaluation of combination level between size of main, additional and auxiliary branches, the number and size of production units, distribution of branches and production units in the production infrastructure ${ }^{6}$.

Most reliable way to set the optimal size of agricultural enterprises and their units is the use of economic-mathematical methods in which more accurately takes into account all the optimizing components of the enterprise.

The basis for the calculation and analytics are standard yields, enterprise structure , cost of labor, assets and materials per hectare of crop, cow, etc. Based on these data , taking into account the specific conditions of production and best results technological maps are made on crops, livestock or pigs breeding. Technological maps includes the use of the most advanced machines and types of equipment, the development of advanced technology and organization of production, the rational for given conditions of farming and animal husbandry.

In determining of the optimal size of production units we are taking into account the following factors:

- effective use of technology. To achieve this goal, based on the structure of sown areas and using technological maps, we calculate the total amount of mechanized operations in periods, types of work and cultures ( work is spread over the brands of tractors used in mechanized operations);

- providing qualified management unit supervisor who shall promptly give the tasks to employees and departments and monitor the performance, quality, properly accounting of performed work in order to ensure high performance and uninterrupted use of technology;

- rational organization of crop rotation on cultivated area, without affecting the effective use of technology. The production branch has usually its own capabilities to serve the full array of crop rotation. Therefore, area assigned to the branch and branch size is interdependent. The area of rotation depends on the number of fields in it, and the average

\footnotetext{
${ }^{5}$ Aleksiichuk V.M, Artykulnyy L.A., Yurchyshyn V. et al., Reform and development of agricultural production enterprises [Text]: questions and answers / Editors P.T. Sabluk - K.: IAE UAAS, 1999. - 362 p. (in Ukrainian)

${ }^{6}$ Aleksiichuk V.M, Artykulnyy L.A., Yurchyshyn V. et al., Reform and development of agricultural production enterprises [Text]: questions and answers / Editors P.T. Sabluk - K.: IAE UAAS, 1999. - 362 p. (in Ukrainian)
} 
size of the field, and the last - of rational length and width of the field in their system of machines, the technology and production conditions ${ }^{7}$.

\section{PRACTICAL IMPLEMENTATION OF PROPOSED RESOURCE SAVING STRATEGY IN AGRICULTURE PRODUCTION}

Given that the number of fields in the rotation depends on the structure of sown areas, we can calculate the area of arable land in the branch and the number of machinery needed for the planned works in crop production. Numbers, provided below are advisable, and calculated based on the experience of the advanced economies. Knowing this information, it is easy to define a rational total area of arable land on the farm in the specific conditions of production. Based on the average proportion of arable land in total land fund economies of the region, we can determine the total average acreage in farms ${ }^{8}$.

For example, in the household average field size is 50 ha $(1000 \mathrm{~m}$ by $500 \mathrm{~m})$. Recommended optimal structure of sown areas : total grain - 55\%, including wheat - $29 \%$, corn $-8 \%$, legumes $-9 \%$, crops $-12 \%$, vegetables and potatoes $-7 \%$, forage and other crops - $26 \%$, including corn silage - $10 \%$, perennial and annual grasses $-17 \%$. With such structure of sown areas enterprise must have 10 rotation of the fields. Thus, the structural unit of management should be 500 hectares of arable land ( 50 hectares to 10 fields ). With such a structure of sown areas, as estimated for each hectare of crop rotation area will account for 7 ha of all reference works, and the entire volume of field work will be 3500 etalon hectares ( 500 ha $x 7$ etalon ha on 1 ha). With an average annual output 700 hectares for one reference tractor in branches should have 5 standard tractors. For etalon tractor taken such machine which makes one etalon hectare per 1-hour shift time ${ }^{9}$.

Average farm should have 5 departments. Share of arable land in the total area of land should be $80 \%$, so the average area of land on the farm will be 2500 ha ( 500 ha $\times 5$ units), including 2000 hectares of arable land (2500 ha x $80 \%: 100 \%$ ), and the total amount of work - 17.5 thousand etalon hectares (2500 ha x 7 et.ha per 1 ha). To perform this amount of work enterprise should have 25 etalon tractors (17,500 hectares: 700 et.ha). After that we should determine the volume of production of crops and livestock. Using the accepted structure of sown areas and proper cultivation technology enterprise would produce 35 centners of fodder units per hectare of arable land and 5 centners of fodder units per hectare of other lands. Thus, the total amount of forage yield is 72.5 thousand centners of fodder units $(2000$ ha of arable land $x 3500 \mathrm{~kg}$ of fodder units per ha +500 hectares of other land x $500 \mathrm{~kg}$ of fodder units per ha of other land) which would be used for the production of animal products.

According to the specialization of agriculture enterprise and adopted scheme output of livestock products available forage is given in proportion $60 \%$ for cattle and $40 \%$ for pigs. Estimated production per 100 hectares of agricultural land will be 600 centners of milk and 150 centners of meat.

\footnotetext{
${ }^{7}$ Malik Mykola Io, Zinovchuk Vitalii V., Sabluk Petro T., Basics of Agricultural Entrepreneurship, Editor Malik M.Io. - Kyiv, 2001., 582 p. (in Ukrainian).

${ }^{8}$ Malik Mykola Io, Zinovchuk Vitalii V., Sabluk Petro T., Basics of Agricultural Entrepreneurship, Editor Malik M.Io. - Kyiv, 2001., 582 p. (in Ukrainian).

${ }^{9}$ Aleksiichuk V.M, Artykulnyy L.A., Yurchyshyn V. et al., Reform and development of agricultural production enterprises [Text]: questions and answers / Editors P.T. Sabluk - K.: IAE UAAS, 1999. - 362 p. (in Ukrainian)
} 
In order to produce named amount of milk per 100 hectares of land, it is necessary to have 20 cows with milk yield $3000 \mathrm{~kg}$ of milk, to produce $100 \mathrm{~kg}$ of meat in live weight per 100 hectares of land - 30 heads of cattle with living weighing 5 centners . In addition 3 head of cattle on 100 hectares of land should be for repair and expanded reproduction of the herd. Thus, the density of cattle on 100 hectares of land will be 53 units $(20$ cows + calves 30 goals for rearing and fattening +3 heads of animals for herd reproduction ), and all the farm should have 1325 head of cattle ( 25 hundreds of hectares of land x 53 head), including 500 cows (25 hundred hectares x 20 cows on 100 hectares of land). Similarly calculated the number of other types of livestock for the enterprise and its business units.

From the size of the farm depends on the effectiveness of the use of machinery and other fixed assets, human resources and production in general. The most important for present-day conditions is a factor of rational use of technology. Studies indicate that the larger the production, the more they are used ${ }^{10}$.

According to the workload standards for the performance of manufacturing operations, agronomic terms of implementation, the structure of sown areas depend on the specialization. The system of crop rotation is determined by the size of the land area in which the most complete use of technology is achieved. The load on the machine is taken into account in the peak period of work. Since the calculations for each individual technology do not give a general picture of the use of all machines, we apply formula which determine comprehensive utilization of machines in the enterprise ${ }^{11}$ :

$$
K_{\mathrm{u}}=\left(\mathrm{K}_{\mathrm{ut}} \times \mathrm{C}_{\mathrm{f}}\right) / \mathrm{C}_{\mathrm{f}}
$$

where $\mathrm{Ku}$ - the coefficient of the complex use of machines;

Kut -utilization of equipment;

Cf - the cost of capital production assets.

Based on the coefficient of the complex use of machines that show where arable land is used most efficient, we could make the economic assessment of production in various areas. To do this, it is needed to define the following economic indicators: gross output value at current prices, the cost of funds at $1 \mathrm{UAH}$ of gross output and the amount of depreciation on $1 \mathrm{UAH}$ of gross output, total cost of 1 UAH of gross output and the amount of gross income per 1 UAH of gross output.

Comparing the figures which are based on the size of land, we could determine the rational size of farms in which achieved the highest rate of use of technology, and in accordance with the lowest depreciation on production, the highest efficiency. The results of the analysis allow to conclude that established size of average 55 hectares of agricultural land in Ukraine farms is irrational .

Rational size farms, calculated by authors using recommendations of collective of NSC "Institute of Agrarian Economy", presented in the Table 3.

10 Ronald Kay, William Edwards, Patricia Duffy, Farm Management, McGraw-Hill Science/Engineering/Math; 7 edition, 2011. - 480 p.

11 Ronald Kay, William Edwards, Patricia Duffy, Farm Management, McGraw-Hill Science/Engineering/Math; 7 edition, 2011. - 480 p. 
As Table. 3 shows the rational size of the private farms with grain specialization should be 300-400 ha, grain and sugar beet - 300-400, potato - 100-150, grain and flax 150-300, veggies - 25-50, gardening and vineyard - 30-60, milk production - 250-400, fattening young cattle - 300-500 and the production of pork - 200-400 hectares of agricultural land, depending on area location ${ }^{12}$.

Table 3. Rational size of farms in Ukraine, ha*

\begin{tabular}{|l|c|c|c|}
\hline \multicolumn{1}{|c|}{ Directions of specialization } & \multicolumn{3}{c|}{ Climatic zones } \\
\hline Grain & Steppe & Forest Steppe & Polissia \\
Grain and sunflower & $300-400$ & $300-400$ & $250-350$ \\
Grain and Sugar beets & $300-400$ & $\mathrm{x}$ & $\mathrm{x}$ \\
Potato & $\mathrm{x}$ & $300-400$ & $\mathrm{x}$ \\
Grain and Flax & $\mathrm{x}$ & $\mathrm{x}$ & $100-150$ \\
Vegetables & $\mathrm{x}$ & $\mathrm{x}$ & $150-300$ \\
fruits and berries & $25-50$ & $25-50$ & $25-50$ \\
vinicultural & $30-60$ & $30-60$ & $25-50$ \\
Production of: & $20-50$ & $\mathrm{x}$ & $\mathrm{x}$ \\
milk & $\mathrm{x}$ & $\mathrm{x}$ & $\mathrm{x}$ \\
cattle meat & $250-400$ & $250-400$ & $200-300$ \\
Pork meat & $300-500$ & $350-500$ & $300-400$ \\
sheep production & $250-400$ & $200-400$ & $200-400$ \\
poultry products & $200-300$ & $200-300$ & $\mathrm{x}$ \\
\hline
\end{tabular}

* Source: authors calculations based on data of NSC"Institute of Agrarian Economy "

The optimal number of livestock animals for farm, specializing in the production of animal products, depending on the size of available arable land is given in Table. 3.4.

Unlike many countries, Ukraine has too little specialized in the production of animal products enterprises. Most of the animal production is carried by private households, because for enterprises animal production not as profitable as producing different kinds of crop production for export. Indexes by which effectiveness of enterprise activity could be evaluated, after all presented proposals implemented on a typical farm, should be as follows: the structure of agricultural land, acreage of commercial products, density of livestock and poultry and production per unit of land area, yield of crops and animal

12 Aleksiichuk V.M, Artykulnyy L.A., Yurchyshyn V. et al., Reform and development of agricultural production enterprises [Text]: questions and answers / Editors P.T. Sabluk - K.: IAE UAAS, 1999. - 362 p. (in Ukrainian) 
performance, the need for structure and forage, the value of fixed assets and availability of workers.

Table 4.The optimal number of animals to farms depending on their specialization*

\begin{tabular}{|c|cc|c|c|c|c|}
\hline \multirow{2}{*}{$\begin{array}{c}\text { Area of } \\
\text { arable } \\
\text { land, ha }\end{array}$} & \multicolumn{6}{|c|}{ Direction of specialization } \\
\cline { 2 - 7 } & Milk production & \multicolumn{2}{c|}{ Beef meat production } & \multicolumn{2}{|c|}{ Pork production } \\
\hline 50 & 60 & 30 & 123 & 6 & 320 & 20 \\
\hline 100 & 120 & 60 & 246 & 12 & 640 & 40 \\
\hline 200 & 240 & 120 & 492 & 24 & 1280 & 80 \\
\hline 300 & 360 & 180 & 738 & 36 & 1920 & 120 \\
\hline 400 & 480 & 240 & 984 & 48 & 2560 & 160 \\
\hline 500 & 600 & 300 & 1230 & 60 & 3200 & 200 \\
\hline
\end{tabular}

* Source: authors calculations on data of NSC"Institute of Agrarian Economy "

The main parameters of farms which are composed of industrial complexes are being developed based on the actual level of production achieved in them or others in their area. In the process of determining the parameters of the business for the future we must as a basis key performance indicators of each of the leading sectors according to soil and climate, economic and technological conditions, their organizational and technical and economic relationships, optimal proportions and ratios based on a normative of rational structure.

These indicators and standards matched with actual enterprise data. On the basis of economic-mathematical methods different models of sustainable production type are developed, followed by checking them on the appropriate model objects. Given the characteristics of zonal design productivity of animals is justified by the type of feeding rations and the need for animal feed . Based on the estimated demand for feed the amount of the required area sown forage crop is determined as well as structure of land .

Calculations show that in the most effective milk production that meet the requirements of industrial technology is complex and mechanized dairy farms from keeping calves under 6 months of age. Thus the rational size of the complex is determined based on the possibility of the cows and other livestock feeds its own production, depending on the area of agricultural land and arable land.The main parameters of the complex business of milk production are shown in Table .5

We took milk yield of 4 thousand $\mathrm{kg}$ of milk per cow as the minimum average amount for local milk breeds. Share of grain crop in the area takes 46-56\% and the output feed from 1 ha of agricultural land 35-45 centners of fodder units. Land size under the complexes for the production of milk in the steppe zone should be 2,3-3 thousand hectares, forest steppe - 2 - 2,25 thousand and Polissia - 1.8-2.2 thsd ha. 
In terms of major systems for the production of animal products particular importance plays the revival of forage mill, which should be the center of science-based animal feed and poultry.

Table 5. Proposed parameters for milk production of 800 cows *

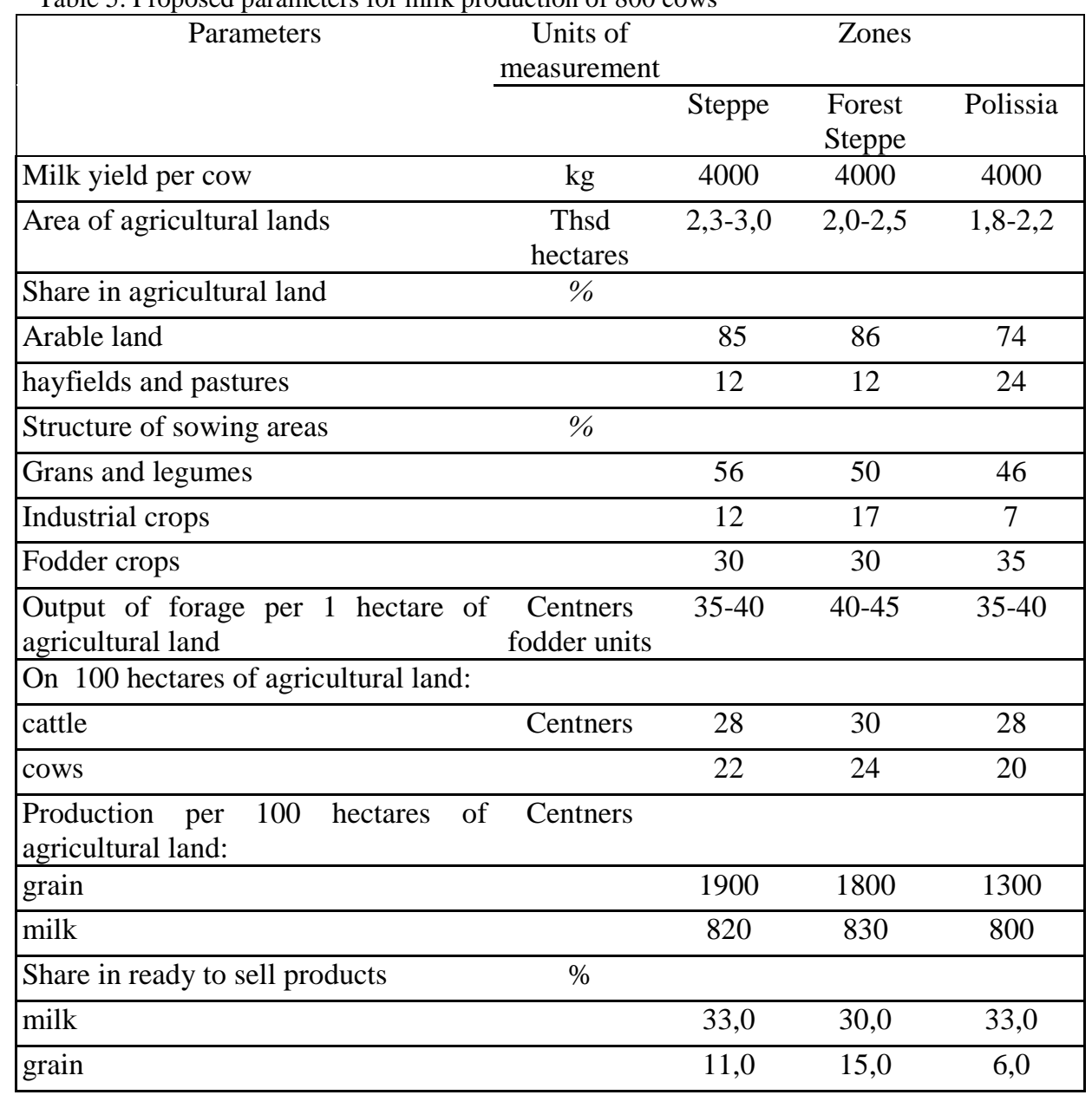

* Source: authors calculations

\section{CONCLUSIONS}

Thus, optimizing the size of agricultural units and their intra- structure, rational combination of sectors and reasonable development of concentration and specialization of production contribute to resource saving in the agricultural sector of the economy. Proposed methods of selecting, building and choosing proper structure of production will allow to implement resource saving strategy based on the local possibilities without adding new difficulties to the production process. Our recommended size and specialization types may not be as profitable as raising corn for export, but if we take as 
optimality criteria stability of production, resource saving and local development, then our proposals would work the best way. Recent agricultural policy direction on animal production and year to year tax exemptions for milk production confirms our incline to animal breeding with large share of grain production.

\section{REFERENCES:}

[1] Aleksiichuk V.M, Artykulnyy L.A., Yurchyshyn V. et al. (1999) Reform and development of agricultural production enterprises [Text]: questions and answers / Editors P.T. Sabluk - K.: IAE UAAS, 1999. - 362 p. (in Ukrainian)

[2] Malik Mykola Io; Zinovchuk Vitalii V.; Sabluk Petro T. (2001). Basics of Agricultural Entrepreneurship Editor Malik M.Io. - Kyiv, 582 p. (in Ukrainian)

[3] Nedava V.E., Burkat V.P., Vlasov V.I., Podoba B.E. (1984) Raising efficiency of cattle breeding, Kyiv, 176 p. (in Russian)

[4] Pogrebniuak P.L. (1979) Intensive beef cattle production in Ukraine, Mocsow, 1979, 239 p.

[5] Ronald Kay, William Edwards, Patricia Duffy (2011). Farm Management. McGraw-Hill Science/Engineering/Math; 7 edition, 2011. - 480 p.

[6] Statistical Yearbook "Agriculture of Ukraine" for 2012. - Kyiv: State Statistics Service of Ukraine, 2013. - 392 p (in Ukrainian)

[7] Statistical Yearbook of Zhytomirska oblast for 2012. - Zhytomir: State Statistics Service of Ukraine, 2013. - $455 \mathrm{p}$ (in Ukrainian)

[8] The concept of the State program for sustainable development of rural areas by 2020 [Cabinet of Ministers of Ukraine № 121-p from February 3th, 2010] / / Government Courier. - 2010. - March 3 (in Ukrainian)

\section{OPTYMALIZACJA PRODUKCJI ROLNEJ NA PODSTAWIE STRATEGII OSZCZĘDZANIA ZASOBÓW}

Autorzy w artykule rozpatrują konieczność opracowania i warianty strategii oszczędzania zasobów za pomocą instrumentów kooperacji i specjalizacji, które zabezpieczą konkretne wyniki realizacji optymalnej struktury produkcji rolnej. Strategia oszczędzania zasobów jak działalność jest nieprzerwaną poprawą eksploatacji zasobów produkcyjnych i krokami po stworzeniu ekonomicznego mechanizmu ich zachowania, który składa się z zasobów, kierowania, finansowania, stymulacje $\mathrm{i}$ tak dalej. Rozwój i doskonalenie strategii oszczędzania zasobów wymagają oceny współpracy i współdziałania dużych, średnich, małych gospodarstw na podstawie współdziałania, która włącza specjalizację. Użycie teorii koncentracji i specjalizacji daje strategie oszczędzania zasobów twardy grunt i przewagi adekwatnego planowania, wysoki poziom precyzji w możliwej do objęcia wzrokiem przyszłości, rozumienie kluczowych wskaźników efektywności, wybór najbardziej efektywnej (optymalnej) decyzji o podziale i użyciu zasobów, żeby zabezpieczyć największa objętość produkcji czy najmniejszą ilość kosztów. W owym że czasie, uważamy, że proces oszczędzania zasobów zgłasza się najbardziej liczący zasobem w systemie stabilnego rozwoju, współdziałania $\mathrm{i}$ współzależności, które bezpośrednio obejmują główne aspekty gospodarczej działalności na wszystkich poziomach gospodarki. Proces realizacji strategii oszczędzania zasobów rozwiązuje konflikt między oszczędzaniącym działaniem nowych 
technologii i możliwości do adaptacji istniejącego mechanizmu ekonomicznego, i doprowadza do podwyższenia wydajności przedsiębiorstwa w przyszłości.

Słowa kluczowe: oszczędność zasobów, koncentracja, specjalizacja, optymalna wielkość, produkcja rolna

DOI:10.7862/rz.2014.hss.50

Przesłano do redakcji: czerwiec 2014

Przyjęto do druku: październik 2014 